\title{
THE EXPERIENCES OF PARENTS WHERE PREGNANACY ENDED IN AN UNPLANNED CAESAREAN SECTION
}

\section{Ceronio, CS Dörfling and AGW Nolte}

\begin{abstract}
The purpose of this study was to determine the experiences of parents priorto, during and following an unplanned caesarean section. Parents who experienced this event had mixed emotions. The related accurrences may have influenced their behaviour and consequently their relationships with their spouses, themsetves and their emvironment. These continually interacted with each other and thus needed to be looked at in context. 'The Nursing of the Whole Person Theory' ensured a holistic approach to the parents.
\end{abstract}

Unstructured, in-depth interviews held with five mothers and five fathers, respectivety; on day three post-delivery, were transcribed and anatysed. At six weeks a follow-up semi-structured questionnaire was answered by these same respondents and analysed The experiences of the parents were then compared.

A literature survey was undertaken in order to determine the conclusions of other researchers in this field, the results of which were compared with those of the present study and conclusions were reached.

Recommendations concerming nursing practice, education and further study were made at the end of the study. $A$ list of limitations affecting the study is included.

\section{OPSOMMING}

Die doel van die studie was om te bepaal wat die belewenisse van ouers, voor, gedurende en na 'n onbeplande keisersnit was. Dit is met gemengde gevoelens dat ouers hierdie gebeurtenis beleef het. Die verwante gebeurtenisse kon die gedrag en uiteindelik ook verhoudings met eggenote/s, self en omgewing beinvloed het. Aangesien hierdie faktore gedurig op mekaar inwerk, moes dit in konteks bestudeer word. Die "Verpleegteorie van Menslike Heelheid" verseker die regte benadering tot die ouers.

Ongestruktueerde diepte-onderhoude, wat drie dae na geboorte met vyf moeders en vy vaders, onderskeidelik en afsonderlik, gevoer was, was getranskribeer en daama geanaliseer. Na ses weke was 'n semi-gestruktueerde opvolgunaelys deur dieselfde respondente voltooi en ook geanaliseer. Die belewenisse van die ouers was daama met mekaar vergelyk.

'n Literatuurkontrole was gedoen om vas te stel wat die gevolgtrekkings van ander skorywers op die gebied was.

Die bevindings van die literatuurkontrole was met die resultate van die studie vergelyk en gevalgtrekkings was bereik Laastens was aambevelings in verband met die verplegingpraknk, opleiding en verdere studie gemaak. Die beperkinge van die studie was genoteer.

\section{BACKGROUND AND SIGNIFICANCE OF THE RESEARCH PROBLEM}

The first caesarean in South Africa was performed in the Cape on the 25th July 1826. Since then many changes have occurred, such as improving on the type of incision, the use of epidural anaesthetics and many more.

Recent statistics show an increase in the performance of caesarean sections, especially in private clinics and this, including facts concerning parents' reactions to an unplanned caesarean section, prompted the researcher to do an in-depth investigation, post-delivery, on how parents were affected by an unplanned caesarean section.

\section{PROBLEM STATEMENT}

The midwife's knowledge of patients' experiences, i.e. physical, psychological and spiritual, is crucial to enable her to facilitate wholeness in the individual who in this case, were the parents-to-be involved in unplanned caesarean sections.

The expected outcome of the study was to increase the midwives', gynaecologists' and community's awareness of the emotions of the parents-to-be resulting from the unexpected caesarean section, as well as their respective roles in the management of these patients.

\section{THEORETICAL ASSUMPTIONS}

Derived from the "Nursing of the Whole Person Theory" (Rand Afrikaans University 1992) the theoretical assumptions are

- The individual is a spiritual being who functions in an integrated bio/psycho/ social manner to achieve his quest for wholeness.

- The individual interacts holistically with his internal and external environment.

- The midwife's approach towards individuals in their childbearing phase focuses on spiritual, physiological and physical aspects of wholeness.

\section{METHODOLOGIC ASSUMPTIONS}

The assumption is that scientific nursing practice must arise from a functional school of thought which means that the aim of such practice is to give action-orientated prescriptions, in a specific context, for the application and improvement of nursing practice. The utilisation and value of the research findings as they relate to improved nursing practice were the criteria for validity.

It was also assumed that research and theory formulation do not take place in isolation but rather relate to nursing practice and the philosophy of nursing science. (Botes, 1991 5). 
The design of this study is exploratory and descriptive. The intention is to try and reconstruct reality from the experiential world of the parents or parents-to-be, aiming to understand them better but not to generalise from data obtained.

Qualitative, phenomenological methodology was be used. This style of research is employed for an in-depth, contextual study to reconstruct the subjectively meaningful worlds of the parents-to-be with emphasis on the 'wholeness' of the human being involved. The context is the maternity section of a private clinic on the West Rand.

\section{RESEARCH METHODOLOGY}

This study will be described in two phases in order to provide a clear reference to the interviews (Phase I) and the questionnaire (Phase II) throughout the study.

\section{PHASE I}

\section{POPULATION SAMPLING}

A population of five white patients and their spouses on the West Rand, who faced an unexpected caesarean section, were approached on day three post-delivery. A small population was chosen as the researcher planned an intense, in-depth study of the respondents' experiences.

This population was chosen purposely and respondents had to be:-

a) Married white men and women from the middle and higher socio-economic status group.

b) Parents of three-day-old infants, following an unexpected caesarean section, the parity being irrelevant. The reasons for respondents being approached only on the third day post-delivery were to ensure that vital signs were stable and that respondents had time to think about their experience.

c) Selected from a privale clinic on the West Rand and be private patients viz. under specialist's care

d) Have been in labour prior to the caesarean section.

e) In addition, all patients had to have undergone an epidural caesarean section in order to prevent external factors such as initial pain, nausea, weak bonding and possible disorientation influencing their experiences.

The above prerequisites made for a "goalorientated" sampling of repondents. They were chosen on arrival in the post-natal ward, following an unexpected caesarcan section Sampling began in February 1992

\section{DATA GATHERING}

The purpose of the study was explained to the respondents, so that they could state whether or not they were prepared to participate.

The respondents were approached in their wards post-delivery while husbands were present. It was made clear that they were under no obligation to participate in the study and to allow for any refusal, the researcher left the parents alone to discuss the matter. Verbal consent was obtained from the respondents; the need for recording their experiences (i.e. for transcription and analysis purposes) was explained and they were assured of anonymity.

Appointments were be arranged to interview the respondents on separate suitable occasions. Interviews were conducted within the matemity section of the private clinic on the respondent's third day post-delivery by the researcher who had completed an inter-communication skills course.

The following question were asked to commence the interview:

"How did you as parent experience the unexpected caesarean from the moment you heard about the decision until now?" The researcher mentioned that this included the physical, psychological and spiritual experience of the respondent.

\section{DATA ANALYSIS}

The interviews were transcribed, with faulty language and repetition left unchanged. The researcher and an external controller (coder) analysed the transcriptions independently, according to the process described in points 1 - 5 below, whereafter the researcher and controller discussed and correlated the content of individual analysis to reach an objective result. The controller was be a nursing researcher.

For analysis of the information in this study, Kerlinger's (1986: 479) content analysis method was used.

1. The researcher began by reading the transcribed interviews thoroughly in order to get an overview of each interview

2 Personal experiences were then underlined in the transcribed interviews

3. The information gained was divided into categories for analysis, i.e. internal environment and external environment and in context with The Nursing of the Whole Person Theory. (Rand Afrikans University, Department of Nursing. 1992:136-142).

4. Catagones were put in tabulated form to add more structure to thought patterns and to aid conclusional data.

5. A final table containing the general experiences of the respondents was drawn up from which recommendations and conclusions were made.
Categories for analysis included

a) Internal Environment: Physical:

The then present physical condition and the medical history.

Psychological

- Cognitive and intelloct

- Emotional

- Decision making and aspirations/volition

Spiritual :

- Purpose and significance

- Values

- Religion

b) Erternal Environment:

Physical :

- Geographical placement of being

Social :

- Relationships with

family and others

- Occupants

- Financial

Spiritual

- Spiritual Relationships

- Values and cultural relationships

\section{LITERATURE CONTROL}

A complete literature control was done after the interview with respoct to the concepts in the research statement. The literature control followed data analysis as completing the literature prior to the interview could influence the researcher's approach and/or objectivity towards the respondents during the interviews.

\section{PHASE II}

\section{DATA GATHERING}

At approximately six weeks post-delivery, follow-up semi-structured questionnaire was given to the same respondents to obtain a subjective retrospection of the whole experience that the parents had lived through as well as new experiences that may have developed during in the interim.

The aim of the questionnaire was to determine whether the parents, in retrospect saw the caesarean as they did initially or if feelings changed as time passed. The questionnaire thus included questions relating to experiences directly following the caesarean section, as well as experiences after six weeks

A question about preference of method of childbirth for future siblings was asked to determine whether the parents had a negative or positive experience, or whether they realised that they could have a choice in this regard

\section{POPULATION SAMPLING}

The same respondents used in Phase I were apprached. In doing this the researcher was able to ensure optimal reliability and validity 
of data. The respondents will also be aware of the purpose of the study and will previously have been informed about the follow-up questionnaire.

\section{DATA ANALYSIS}

The questionnaires were collected and treated as a semi-structured recording. The same method of analysis (Kerlinger 1986: 479) followed and points 1 - 5 were repeated. Such analysis was seen as contributing data to the final results of the study and were be correlated with the completed literature control.

\section{RELIABILITY AND VALIDITY OF DATA COLLECTION}

\section{Reliability}

The reliability of qualitative studies is dependent upon an independent researcher who is able to generate the same constructs in a similar situation, or place the data in the same previously generated constructs. (Burns \& Grove, 1987; 23) The factors influencing the reliability of the study in the case of the interviews (Phase I) could possibly be:

\section{The Researcher's Status Position}

In this study the researcher was a female nursing sister and midwife on duty in the labour ward. She had to be aware that the respondents could answer what they felt was expected from them instead of relating their actual experiences.

\section{The Choice of Respondents}

In order to maintain reliability, the choice of respondents occurred accidentally as the patient entered the post-natal ward, following an unexpected caesarean section, provided that they met the selection prerequisites.

\section{RESULTS AND \\ RECOMMENDATIONS}

The results of this study are tabulated in order to compare the data collected with that of existing literature. There is evidently not sufficient existing literature on the subject under discussion.

The results are discussed within the categories for analysis.

\section{a) THE MOTHERS' EXPERIENCES}

\section{Internal Environment}

\section{Dody}

The mothers mainly experienced exhaustion and pain, either prior to, during or after the caesarean section. The literature substantiates this by stating that the mothers suffered such fatigue that they could not handle their frustrations and were oflen tired for many months. (Nolte, 1991: 38)
Mothers experienced tremors and could not relax prior to the caesarean, as they felt ignorant of events to follow. It was also evident that the mothers, being immobile or trapped in bed by apparatus following the caesarean section, experienced a great deal of frustration and difficulty in managing their maternal tasks.

It thus can be said that mothers experienced the caesarean as physically disturbing and that it hindered their functioning abilities post-delivery.

\section{Psyche}

Intellect

The majority of the mothers in the study were critical of mangement of the caesarean and related procedures.

Three mothers stressed that they had not felt robbed of experiencing a natural birth. Since they were not asked this, why then was it important for them to state this emotion? Is it that society places pressure on the parents to have a natural birth? Most literature states that a mother could feel robbed of experiencing a natural birth

\section{Emotion}

Emotions such as despair, frustration, fear/anxiety, panic and disappointment were experienced by most of mothers, but the strongest emotion was a fear of the unknown, i.e. the caesarean section. Positive emotions only featured following the operation, i.e. relief, acceptance and tenderness and it may be deduced that these mothers had a less satisfying experience of birth than they had expected. At six weeks mothers felt that they had been left out of the parenting role, they could not hold or nurture their infants immediately. Some expressed anger at having had a caesarean.

\section{Volition}

Mothers felt that they had no say in the decision to perform a caesarean section as the decision was made for them, leaving them to think there was no option. Mothers only played an observing role.

\section{Spiritual}

The majority of the mothers expressed that it was important to them to have had a natural birth as they had set their minds on there being no other alternative; this wish was unfulfilled.

\section{External Environment}

• Physical

The literature does not discuss this factor as having any effect on the patients, but the mothers in the study mentioned the theatre drapings over them, and feared upsetting the sterility. Mothers also felt that bonding was hindered by the theatre atmosphere. The urinary catheter and intravenous infusion complicated movements post-caesarean section and thus mangement of self and baby was affected detrimentally.

\section{Social}

Although the father's presence during the caesarean section was stated as being highly important in the literature, only two mothers from the study mentioned this as supportive during the caesarcan section.

\section{Social}

One mother said that it was not important how the infant was born, as long as it was brought into the world successfully. The study did not cover the spiritual aspect adequately.

\section{b) THE FATHERS' EXPERIENCES}

\section{Interaal Environment}

Body

Only experiences of feeling faint and physically shaken were stated. The literature mentions that fathers often feel exhausted, but the study found that they were rather too excited and shocked to feel exhausted.

\section{Psyche}

\section{Intellect}

Fathers had to rationalise the events that occurred over and over, so as to remain in control of themselves and their environment. The fathers asked many questions; they wanted to understand why their wives had to have drips, urinary catheters and so forth, as if having a logical explanation for events helped them to cope. Acceptance of the caesarean section was casier for those fathers who understood the reasons for the procedures.

Most fathers felt that they were totally unprepared and lacked knowledge concerning the caesarean section.

\section{Emotions}

The fathers experienced disappointment as the most intense emotion and said that they would not recommend anyone to have a caesarean section. No feelings of exclusion were noted in the study but rather the feeling of possession towards their infants as they had first opportunity to hold and nurture them. The literature described the feelings of joy and pride the fathers had towards their newborn.

\section{Volition}

The fathers felt they had been coerced into the situation of a caesarean section being performed without feeling adequately prepared and, therefore, did not feel in control of the occurrences 


\section{Spiritual}

The majority of the fathers expressed the wish to have seen their wives give natural birth. From the literature it was clear that both parents expressed the need to experience natural birth.

\section{External Environment}

\section{Physical}

The fathers found the theatre, theatre clothes, temperature in the theatre and the prospect of blood very disturbing and contributing factors to their raised anxiety levels during the caesarean section

\section{Social}

The nursing staff were seen as playing an important role in the fathers' experience of the caesarean section. One father stated that he felt a natural birth would have brought him and his wife closer together.

It was clear from the study that support from health care personnel was of cardinal importance to the fathers who experienced such events, and therefore could help to facilitate easier acceptance of the occurrences

\section{Dpiritual}

It appears from literature that the norm in society is to have a natural birth, but the study did not include direct questioning relating to the external spiritual world of the parents

\section{PATTERNS OF INTERACTION}

The mothers experienced a lot of frustration as a result of immobility which led to difficult management of expected maternal tasks and self-care. Bonding with their infants was often delayed while the mother tried to recover from the initial shock, discomfort and despair of having a caesarean section.

The first hour, according to Klaus and Kennel (1982) is crucial for attachment to occur between parent and infant, as the infant is most alent at this time. In this study the mothers experienced feelings of being left out from touching and caring for the infant as they were bound to the theatre bed, while fathers were able to hold examine and partake in the care of the infant directly after the birth. Bonding between father and infant was possible at a very early stage as they were all present at the birth.

\section{RECOMMENDATIONS}

\section{Nursing Practice}

In practice, the aim should be to allow any woman the "joy of accomplishment connected with mastery of fear and pain and the happy relations with the baby immediately after deliven:" (Cox \& Smith, 1982: 309)
Brumbaugh (1982): 312), a nurse who encourages vaginal birthing, feels that should a caesarean section be performed, it is important to provide the mother with attention and support, identifying the emotional sequelae, handling it, and eventually helping her to accept it. This advice can be instituted in any matemity section.

Nursing interventions for parents experiencing the unplanned caesarean section should be included in the maternity ward policy to facilitate better management, crisis prevention and more satisfying experience.

\section{Education}

In general, authors feel that if nurses could accept a caesarean section as an altemative method of birth and demonstrate this acceptance by the correct terminology usage, they could start to assist parents in accepting a caesarean section and in so doing reduce the emotional conflicts surrounding such a delivery. Words such as 'normal/natural birth' or the 'section' in room $4 \mathrm{c}$, should be omitted. (Leach \& Sproule, 1984: 191)

Nurses who are involved in the educational system should include the procedure of an unplanned caesarean section in all pre-natal preparation classes and encourage rooming-in during the post-natal period. Rooming-in can help to provide adequate time for bonding between infant and parents, but it can also add to the mother's frustrations if she is not yet able to manage the infant. A balance must thus be found for each individual.

It is, of cardinal importance that the parents' experiences and the midwife's management and guidance of such parents be added to the basic midwifery-educational curriculum. The midwife should also be capable of effective communication skills in order to assist and guide these parents effectively. These communication skills should also be incorporated in the basic educational system and include prescribed guidelines for correct management of crisis situations such as the unplanned caesurean section.

\section{LIMITATIONS OF THE RESEARCH}

- An obvious limitation to this study is the small population sample which precluded any generalisation of data, thus necessitating further research

- The nature of the question asked by the researcher, i.e how they experienced the unplanned caesarean section, may have influenced the parents' responses. They may have felt that they were expected to react in a specific manner which, in turn, might have had an influence in the relating of their experiences. Emotions may thus have been suppressed or only partly discussed

- Coincidentally, the parents in this study were all first-time parents. This would obviously have an effect on the study as many multiparous women would have had a previous experience of birthing with which to compare the caesarean section

- Lastly, the use of a tape-recorder during the interview seemed to unsettle parents and may have influenced their comments.

\section{REFERENCES}

Botes, A (1991): ' $n$ Model vir navorsing in die verpleegkunde. Werkstuk, Randse Afrikanse Universiteit.

Brumbaugh, P (1982) : Self-esteem - A concern. American Joumal of Matemal Child Nursing, 7, 1982:312.

Cox, BE \& Smith, EC (1982) : Mothers' self-esteem after caesarean delivery, American Journal of Maternal Child Nursing, 7 SeptOct 1982:309-312. '

Kerlinger, FN (1986) : Foundations of behavioral research. New York: Holt, Rinehart and Winston.

Klaus, MH \& Kennel, JH (1982): Parent-infant bonding: Second Edition. London: Mosby.

Leach, L \& Sproule, V (1984): Meeting the challenge of caesarean births. Journal of Obstetric, Gynaecologic and Neonatal Nursing, May/June 1984 : 191-195.

Nolte, AGW (1991) : Care by the midwife during the postnatal period. Werkstuk, Randse Afrikananse Universiteit.

RAND AFRIKAANS UNIVERSITY : Department of Nursing (1992) : 136-142 Nursing of the Whole Person Theory. Oral Roberts University Anna Vaughn School of Nursing, 1991: 136-141.

C.C Ceronlo
B.Cur, M.Cur (Rand Afrikaans
University)
Registered Nurse and Midwite
C.S. Dórfling
B.Cur, M.Cur, PhD(Midwitery and
Neonatogy Nursing)
Registered Nurse and midwite
Lecturer in Midwitery - Department of
Nursing
Rand Afrikeans University
A.G.W. Nolte
B.Soc.Sc, M.Soc.Sc. PhD(Midwitery
and Neonatology Nursing)
Registered Nurse and midwite
Professor in Midwilery - Department of
Nursing
Rand Arikaans University

